\title{
Peran Return on Equity, Debt to Equity Ratio dan Cash Ratio dalam Mempengaruhi Dividend Payout Ratio pada Perusahaan Go-Publik Sektor Barang Konsumsi Tahun 2014-2018
}

\section{The Role of Return on Equity, Debt to Equity Ratio and Cash Ratio in Influencing Dividend Payout Ratio on Go-Public Companies of Consumer Goods Sector in Year of 2014-2018}

\author{
Meliana Meliana ${ }^{1)}$, Wirda Lilia $^{2)}$, Siska Siska ${ }^{3)}$, Andreas Andreas $^{4)}$ \\ ${ }^{1,2,3,4)}$ Fakultas Ekonomi, Universitas Prima Indonesia, Kota Medan \\ e-mail korespondensi:melianaaa28@gmail.com
}

\begin{tabular}{|l|}
\hline Info Artikel \\
\hline Riwayat Artikel : \\
Diterima: 21 Februari 2020 \\
Disetujui: 02 Juli 2020 \\
Dipublikasikan: Juli 2020 \\
\hline Nomor DOI \\
10.33059/jseb.v11i2.2117 \\
Cara Mensitasi : \\
Meliana, Lilia, W., Siska \& \\
Andreas. 2020. Peran Return \\
on Equity, Debt to Equity \\
Ratio dan Cash Ratio dalam \\
Mempengaruhi Dividend \\
Payout Ratio pada Perusahaan \\
Go-Publik Sektor Barang \\
Konsumsi Tahun 2014-2018. \\
Jurnal Samudra Ekonomi \\
dan Bisnis. 11(2): 237-250.
\end{tabular}

\begin{tabular}{|l|}
\hline Article Info \\
\hline Article History : \\
Received: 21 February 2020 \\
Accepted: 02 July 2020 \\
Published: July 2020 \\
\hline
\end{tabular}

DOI Number :

10.33059/jseb.v11i2.2117

How to cite :

Meliana, Lilia, W., Siska \& Andreas. 2020. Peran Return on Equity, Debt to Equity Ratio dan Cash Ratio dalam Mempengaruhi Dividend Payout Ratio pada Perusahaan Go-Publik Sektor Barang Konsumsi Tahun 2014-2018. Jurnal Samudra Ekonomi dan Bisnis. 11(2): 237-250.
Penelitian ini bertujuan untuk menganalisis peran dari Return on Equity, Debt to Equity Ratio dan Cash Ratio dalam mempengaruhi Dividend Payout Ratio pada perusahaan go-publik sektor barang konsumsi tahun 2014-2018. Penelitian ini merupakan penelitian deskriptif kuantitatif yang bersumber dari data keuangan di situs Bursa Efek Indonesia. 18 perusahaan dipilih sebagai sampel secara purposive dari 47 perusahaan sektor barang konsumsi yang menjad anggota populasi. Hasil penelitian menunjukkan bahwa secara parsial, Return on Equity dan Debt to Equity Ratio terbukti memiliki peran yang signifikan dalam mempengaruhi Dividend Payout Ratio; sedangkan Cash Ratio terbukti tidak berpengaruh signifikan terhadap Dividend Payout Ratio. Secara simultan, Return on Equity, Debt to Equity Ratio dan Cash Ratio terbukti berperan secara signifikan dalam mempengaruhi Dividend Payout Ratio.

Kata Kunci: Return on Equity, Debt to Equity Ratio, Cash Ratio, Dividend Payout Ratio.

Abstract

The study aims to analyze the role of Return on Equity, Debt to Equity Ratio and Cash Ratio in influencing Dividend Payout Ratio on go-public companies of consumer goods sector in the year of 2014-2018. This quantitativedescriptive research sourced from financial data on the Indonesia Stock Exchange website. 18 companies were selected as a sample purposively from 47 companies in the consumer goods sector that were members of the population. The results showed that partially, Return on Equity and Debt to Equity Ratio were proven to have a significant role in influencing Dividend Payout Ratio; while Cash Ratio is proven to have no significant effect on Dividend Payout Ratio. Simultaneously, Return on Equity, Debt to Equity Ratio and Cash Ratio were proven to have a significant role in influencing Dividend Payout Ratio.

Keywords: Return on Equity, Debt to Equity Ratio, Cash Ratio, Dividend Payout Ratio. 


\section{PENDAHULUAN}

Perkembangan teknologi saat ini yang memasuki industri 4.0, diharapkan adanya persaingan yang ketat antara perusahaanperusahaan dalam upaya meningkatkan laba perusahaan, sehingga khususnya di pasar modal bisa meningkatkan dividen serta juga mampu mempertinggi nilai perusahaannya. Tetapi untuk memperoleh dividen yang besar tidaklah mudah karena adanya keputusan yang sulit dan dilematis bagi setiap perusahaan dalam menentukan kebijakan dividen.

Kebijakan dividen pada penelitian ini dapat dilihat pada Dividend Payout Ratio (DPR), yaitu rasio yang mengukur besaran bagian laba bersih setelah pajak yang dibayarkan sebagai dividen kepada pemegang saham (Sudana, 2015). DPR adalah perbandingan nilai dividen yang dibagikan per lembar saham terhadap nilai Earning per Share (EPS) atau jumlah laba per lembar saham yang dicapai perusahaan (Darmadji \& Fakhruddin, 2012). Kebijakan tentang DPR ini dinilai sangat berhubungan pada kinerja keuangan yang dicapai perusahaan (Winarko, 2017). Apabila kinerja perusahaan dalam aspek keuangan dinilai bagus maka perusahaan itu mampu menentukan besaran DPR yang sesuai harapan pihak pemegang saham, dan dengan tanpa mengabaikan kepentingan pihak perusahaan agar tetap bisa eksis dan mengalami pertumbuhan.

Penelitian ini memilih perusahaan gopublik sektor barang konsumsi sebagai obyek dikarenakan merupakan salah satu perusahaan manufaktur yang bisa memberikan kontribusi besar bagi pertumbuhan ekonomi Indonesia. Dengan kata lain, perusahaan yang tergabung ke dalam industri barang konsumsi memiliki tingkat persaingan yang tinggi, sehingga sebagian besar perusahaan sektor barang konsumsi bisa memberikan keuntungan sesuai dengan perekonomian perusahaan. Meskipun memiliki tingkat persaingan tinggi, masih banyak perusahaan sektor barang konsumsi ini belum bisa memberikan dividen secara teratur, padahal kebijakan ini yang menjadi salah satu pertimbangan utama investor dalam berinvestasi di Indonesia.

Terdapat beberapa faktor yang dinilai memiliki peran dalam mempengaruhi perubahan yang terjadi atas DPR, di antaranya adalah Return on Equity (ROE), Debt to Equity Ratio (DER) dan Cash Ratio. ROE mewakili ukuran profitabilitas yaitu kemampuan perusahaan menghasilkan laba dari operasi bisnisnya; DER mewakili ukuran solvabilitas yaitu rasio kemampuan perusahaan mengelola total hutangnya sebagai sumber pendanan bisnisnya; serta, Cash Ratio mewakili ukuran likuiditas yaitu kemampuan perusahaan memenuhi beban kewajiban jangka pendek saat jatuh tempo. Perubahanperubahan yang terjadi atas ketiga rasio kinerja perusahaan tersebut dinilai dapat mempengaruhi variasi yang terjadi atas DPR.

Berdasarkan fenomena yang telah diuraikan, tujuan yang ingin dicapai melalui penelitian ini adalah untuk melakukan analisis atas peran dari ROE, DER dan Cash Ratio dalam mempengaruhi DPR pada perusahaan go-publik sektor barang konsumsi, baik secara parsial atau simultan.

\section{Peran ROE terhadap DPR}

Salah satu faktor yang dipandang berperan mempengaruhi DPR adalah Return on Equity (ROE), yang mengindikasikan kemampuan perusahaan dalam memperoleh laba perusahaan yang besar. ROE sebagai salah satu dari rasio profitabilitas dan merupakan indikator yang sangat penting bagi pihak pemegang saham maupun investor dalam melakukan penilaian atas kemampuan perusahaan untuk memperoleh laba bersih, dan selanjutnya berkaitan dengan pembagian dividen (Lioew et al., 2014; Kasmir, 2012). ROE adalah perbandingan antara laba bersih 
setelah pajak terhadap jumlah modal sendiri yang dimiliki perusahaan (Kasmir, 2012; Sudana, 2015). Semakin tinggi nilai ROE bisa menunjukkan semakin meningkatnya kemampuan perusahaan menghasilkan keuntungan dengan menggunakan ekuitas miliknya.

Kebijakan dividen yang ditentukan perusahaan sering dihubungkan dengan capaian rasio ROE (Sarmento \& Dana, 2016; Lioew et al., 2014). Nilai ROE yang tinggi menunjukkan semakin besar nilai laba bersih yang dicapai perusahaan dalam aktivitas usahanya; dan kondisi ini dinilai akan mengarah pada semakin besar nilai dividen yang dibagikan pada para pemegang saham. Sebaliknya, jika ROE bernilai rendah maka menunjukkan semakin kecil laba bersih yang diperoleh perusahaan; dan selanjutnya akan mengarah pada semakin kecil dividen yang dibagikan pada pemegang saham. Hal ini sesuai Smoothing theory yang berargumen jumlah dividen yang dibagikan perusahaan adalah bergantung kepada keuntungan bersih perusahaan sekarang dan dividen sebelumnya.

Berdasarkan pemikiran yang telah diuraikan mengenai peran dari ROE dalam mempengaruhi kebijakan dividen (DPR), maka hipotesis pertama yang dimunculkan adalah:

H1 : ROE secara parsial memiliki peran yang signifikan dalam mempengaruhi DPR di perusahaan go-publik sektor barang konsumsi tahun 2014-2018.

\section{Peran DER terhadap DPR}

Debt to Equity Ratio (DER) juga dinilai memiliki peran mempengaruhi DPR. DER menunjukkan kemampuan membayar jumlah hutang yang dimiliki perusahaan, yaitu sebagai ukuran untuk memperlihatkan besarnya jaminan yang disediakan perusahaan untuk kreditor (Fahmi, 2016). DER adalah perbandingan antara total hutang yang membebani perusahaan dengan nilai ekuitas perusahaan (Van Horne \& Wachowicz, 2012). Nilai DER yang semakin tinggi menunjukkan semakin besar penggunaan modal hutang oleh perusahaan dibandingkan penggunaan modal sendiri; atau sebaliknya, jika nilai DER semakin rendah menunjukkan semakin kecilnya penggunaan modal hutang dibandingkan modal sendiri perusahaan (Atmoko et al., 2017; Kautsar, 2012).

Penggunaan utang yang terlalu tinggi sebagai sumber pendanaan bisa menyebabkan perusahaan harus menanggung beban tetap berupa pokok pinjaman dan pembayaran bunga yang semakin besar pula (Purnomo \& Widianti, 2017). Lebih jauh, beban pokok pinjaman dan bunga hutang yang semakin besar itu akan menggerus jumlah laba bersih setelah pajak yang diperoleh perusahaan melalui aktivitas bisnisnya. Dengan demikian, semakin tinggi DER maka semakin kecil dividen yang bisa dibagikan pada pemegang saham, karena kewajiban membayar utang lebih diutamakan daripada dividen (Hanif \& Bustamam, 2017; Winarko, 2017). Konsekuensinya, para investor akan memiliki persepsi negatif kepada perusahaan serta cenderung membuat pertimbangan mengurangi jumlah dana investasi yang ditanamkan dalam perusahaan.

Berdasarkan uraian pemikiran mengenai peran DER dalam mempengaruhi kebijakan dividen (DPR), maka hipotesis kedua yang dimunculkan adalah:

H2 : DER secara parsial memiliki peran yang signifikan dalam mempengaruhi DPR pada perusahaan go-publik sektor barang konsumsi tahun 2014-2018.

\section{Peran Cash Ratio terhadap DPR}

Selain ROE dan DER, Cash Ratio juga dinilai memiliki peran dalam mempengaruhi DPR. Cash Ratio menunjukkan seberapa besar kemampuan likuiditas dari perusahaan, atau menunjukkan kemampuan kas atau setara 
kas perusahaan yang tersedia untuk memenuhi ataupun membayar kewajiban jangka pendeknya saat jatuh tempo (Janifairus et al., 2013). Cash Ratio adalah perbandingan nilai kas dan setara kas yang dimiliki perusahaan terhadap nlai kewajiban lancar yang harus dipenuhi perusahaan (Hery, 2016). Peningkatan Cash Ratio menunjukkan semakin tinggi kemampuan perusahaan menjaga sustainabilitas bisnisnya; sebaliknya, jika nilai Cash Ratio semakin menurun maka dapat mengarahkan perusahaan menuju bangkrut.

Posisi Cash Ratio dipandang merupakan variabel yang penting untuk dipertimbangkan oleh manajemen dalam kebijakan DPR karena mempengaruhi penilaian pemegang saham ataupun investor atas perusahaan (Ambarwati, 2017; Winarko, 2017; Farida \& Sunandar, 2015). Nilai Cash Ratio yang tinggi bisa menunjukkan bahwa perusahaan memiliki kemampuan likuiditas yang tinggi, sehingga lebih besar porsi dari laba bersih yang diperoleh bisa dibayarkan dalam bentuk dividen. Sementara itu, jika perusahaan dinilai mengalami kendala likuiditas maka mengarahkan pihak manajemen untuk membatasi nilai pembagian dividen. Karena itu, nilai Cash Ratio dipandang bisa mempengaruhi besaran dividen yang dibagikan perusahaan.

Berdasarkan pemikiran yang diuraikan mengenai hubungan antara Cash Ratio dan kebijakan dividen (DPR), maka hipotesis ketiga yang dimunculkan yaitu:

H3 : Cash Ratio secara parsial memiliki peran yang signifikan dalam mem- pengaruhi DPR pada perusahaan gopublik sektor barang konsumsi tahun 2014-2018.

Terakhir, penelitian ini menganalisis peran simultan dari ROE, DER dan Cash Ratio dalam mempengaruhi kebijakan dividen (DPR). Hipotesis keempat terkait dengan peran simultan ini yang dimunculkan adalah:

H4: ROE, DER dan Cash Ratio secara simultan mempunyai peran signifikan dalam mempengaruhi DPR perusahaan go-publik sektor barang konsumsi tahun 2014-2018.

\section{METODE PENELITIAN}

Obyek penelitian adalah perusahaan gopublik sektor barang konsumsi. Periode penelitian adalah tahun 2014 sampai 2018. Penelitian deskriptif-kuantitatif ini menggunakan data sekunder yang bersumber dari website BEI (www.idx.co.id). Pengumpulan data sekunder memakai studi dokumentasi.

Populasi selama periode penelitian itu sebanyak 47 perusahaan. Sampel dipilih secara purposive, dimana kriteria yang digunakan bahwa perusahaan itu terdaftar di BEI selama tahun 2014-2018, mempublikasikan laporan keuangan secara rutin selama periode tersebut, dan juga membayar dividen secara rutin selama periode itu. Berdasarkan kriteria itu, terpilih 18 perusahaan sebagai sampel penelitian dengan total observasi sebanyak 90 data. Perincian dari proses pemilihan sampel ditunjukkan dalam Tabel 1.

\section{Tabel 1. Penentuan Sampel}

\begin{tabular}{clc}
\hline No. & \multicolumn{1}{c}{ Keterangan } & Jumlah \\
\hline 1 & Perusahaan yang terdaftar di Bursa Efek Indonesia periode 2014 & 47 \\
2 & Perusahaan yang tidak mempublikasi laporan keuangan secara rutin periode & $(6)$ \\
& $2014-2018$ & $(23)$ \\
3 & Perusahaan yang tidak membayarkan dividen secara berturut & 18 \\
\hline 4 & Jumlah perusahaan yang terpilih menjadi sampel penelitian & 90 \\
\hline
\end{tabular}

Sumber: Data sekunder diolah, 2019. 
Model analisis penelitian ini mencakup empat variabel, yaitu tiga variabel independen dan satu variabel dependen. Variabel independen terdiri dari Return on Equity (ROE), Debt to Equity Ratio (DER), dan Cash Ratio. Variabel dependen adalah Dividend Payout Ratio (DPR). Skala pengukuran dari masingmasing variabel itu adalah rasio.

\section{Metode Analisis Data Analisis Deskriptif}

Tahap pertama dari metode analisis data adalah melakukan analisis statistik deskriptif yang bertujuan memberi gambaran tentang variabel-variabel penelitian. Tahap deskriptif ini dilakukan dengan menganalisis nilai minimum dan maksimum, nilai rata-rata dan standar deviasi (Ghozali, 2016).

\section{Uji Asumsi Klasik}

Tahap kedua adalah menjalankan uji asumsi klasik yang meliputi uji normalitas, uji multikolinearitas, uji autokorelasi, serta uji heteroskedastisitas.

Uji normalitas ditujukan untuk menguji kemungkinan data penelitian telah terdistribusi normal (Ghozali, 2016). Uji normalitas bisa dilakukan melalui dua cara, yaitu analisis grafik dan uji statistik (Sanusi, 2014; Ghozali 2016). Secara grafik, data telah terdistribusi normal jika titik-titik pola data terlihat menyebar di sekitar garis normal pada Grafik Normal Probability Plot. Uji statistik menggunakan pendekatan Kolmogorov-Smirnov dimana data dinyatakan telah terdistribusi normal jika nilai Asymp. Sig (2-tailed) lebih besar dari $0,05(\alpha)$.

Uji multikolinearitas dijalankan untuk menguji kemungkinan adanya korelasi antar variabel independen di dalam model analisis (Ghozali, 2016). Nilai cut-off yang biasa dipakai sebagai kriteria yang menunjukkan tidak ada multikolinearitas yaitu jika nilai
Tolerance lebih besar dari 0,10 ataupun jika nilai VIF lebih kecil dari 10 (Sanusi, 2014).

Uji autokorelasi dilakukan untuk menguji kemungkinan terdapatnya korelasi antara kesalahan pengganggu pada periode $t$ dengan kesalahan pada periode $t$-1 dalam model analisis (Ghozali, 2016). Untuk mendeteksi kemungkinan adanya persoalan auto-korelasi adalah melalui uji Durbin Watson (DW), dengan kriteria bahwa jika nilai DW (d) berada di antara $d u$ dan $4-d u$ berarti tidak terdapat masalah autokorelasi di dalam model regresi (Sanusi, 2014; Ghozali 2016).

Uji heteroskedasitas ditujukan untuk melihat kemungkinan adanya problema dalam model analisis terkait ketidaksamaan variance dari residual suatu pengamatan kepada pengamatan lainnya (Ghozali, 2016). Cara pengujian persoalan heteroskedastisitas dijalankan melalui analisis grafik Scatterplot dan dengan analisis statistik menggunakan uji Park (Ghozali, 2016; Sanusi, 2014). Kriteria pada grafik Scatterplot bahwa model analisis tidak memiliki masalah heteroskedastisitas adalah jika titik-titik pola data menyebar baik di atas serta di bawah angka nol (0) pada sumbu Y. Kriteria analisis statistik adalah bahwa jika nilai signifikansi (Sig.) dari setiap variabel independen berdasarkan hasil uji Park diperoleh lebih besar dari $\alpha(0,05)$ maka dinyatakan model regresi tidak memiliki masalah heteroskedastisitas.

\section{Analisis Regresi Berganda}

Tahap berikutnya adalah melakukan analisis regresi berganda. Analisis ini dimaksudkan untuk mengetahui arah dan besaran pengaruh dari setiap variabel independen atas variabel dependen (Ghozali, 2016). Model regresi berganda di dalam penelitian meliputi tiga variabel independen yaitu Return on Equity (X1), Debt to Equity Ratio (X2) dan Cash Ratio (X3); sementara 
variabel dependen adalah Dividend Payout Ratio (Y).

Pada tahapan ini juga dilakukan analisis koefisien determinasi, yaitu untuk mengukur seberapa besar kemampuan dari model analisis yang digunakan untuk menerangkan perubahan dari variabel dependen (Ghozali, 2016). Pengukuran koefisien determinasi dilihat pada nilai Adjusted $R^{2}$, karena nilai ini akan berubah bila ditambahkan variabel lain dalam model penelitian.

\section{Uji Hipotesis}

Tahap terakhir adalah melakukan uji hipotesis penelitian. Uji hipotesis ini mencakup uji parsial (uji $t$ atau $t$-test) serta uji simultan uji $F$ atau $F$-test).

Uji statistik $t$ pada intinya mengidentifikasi derajat signifikansi dari pengaruh satu variabel independen secara parsial terhadap variabel dependen (Ghozali, 2016). Kriteria pengambilan keputusan adalah jika nilai Sig. $t$ lebih kecil dari 0,05 $(\alpha)$ maka dinyatakan variabel independen mempunyai pengaruh parsial yang signifikan pada variasi dari variabel dependen; sebaliknya, jika nilai Sig. $t$ lebih besar dari 0,05 $(\alpha)$ maka dinyatakan variabel independen tidak memiliki pengaruh parsial yang signifikan terhadap variabel dependen (Sanusi, 2014; Ghozali, 2016).

Sementara itu, uji statistik $F$ menunjukkan derajat signifikansi dari pengaruh semua variabel independen yang dicakup dalam model analisis secara simultan atas variasi dari variabel dependen (Ghozali, 2016). Kriteria pengambilan keputusan adalah jika Sig. $F$ bernilai lebih kecil dari 0,05 $(\alpha)$ maka semua variabel independen dalam model analisis dinyatakan memiliki pengaruh simultan yang signifikan terhadap variasi dari variabel dependen; sebaliknya, jika Sig. $F$ bernilai lebih besar dari 0,05 $(\alpha)$ maka semua variabel independen dalam model analisis dinyatakan tidak memiliki pengaruh simultan yang signifikan atas variabel dependen (Sanusi, 2014; Ghozali, 2016).

\section{HASIL ANALISIS \\ Hasil Analisis Deskriptif}

Bagian ini menguraikan hasil analisis deskriptif atas jumlah data pengamatan (N) pada perusahaan go-publik sektor barang konsumsi sebanyak 90 observasi selama lima tahun, yaitu dari tahun 2014 sampai 2018. Rangkuman tentang hasil analisis deskriptif ditunjukkan dalam Tabel 2.

Berdasarkan Tabel 2 dan dikombinasi dengan data dokumentasi lapangan bisa diuraikan hasil analisis deskriptif untuk setiap variabel independen. Variabel ROE (X1) memiliki nilai mean sebesar 0,312137 (dengan standar deviasi 0,4003199); dimana nilai minimum sebesar 0,0349 terletak pada PT. Chitose Internasional Tbk. di tahun 2018, sementara nilai maksimum sebesar 2,2446 dimiliki PT. Merck Tbk. tahun 2018.

Tabel 2. Hasil Analisis Deskriptif

\begin{tabular}{lccccc}
\hline & $\mathrm{N}$ & Minimum & Maximum & Mean & Std. Deviation \\
\hline $\mathrm{X} 1$ & 90 & .0349 & 2.2446 & .312137 & .4003199 \\
$\mathrm{X} 2$ & 90 & .0709 & 3.0286 & .751308 & .6331673 \\
$\mathrm{X} 3$ & 90 & .0048 & 6.0516 & 1.129332 & 1.2810598 \\
$\mathrm{Y}$ & 90 & .0837 & 1.5400 & .534803 & .3172716 \\
Valid N (listwise) & 90 & & & & \\
\hline
\end{tabular}

Sumber: Data sekunder diolah, 2019. 


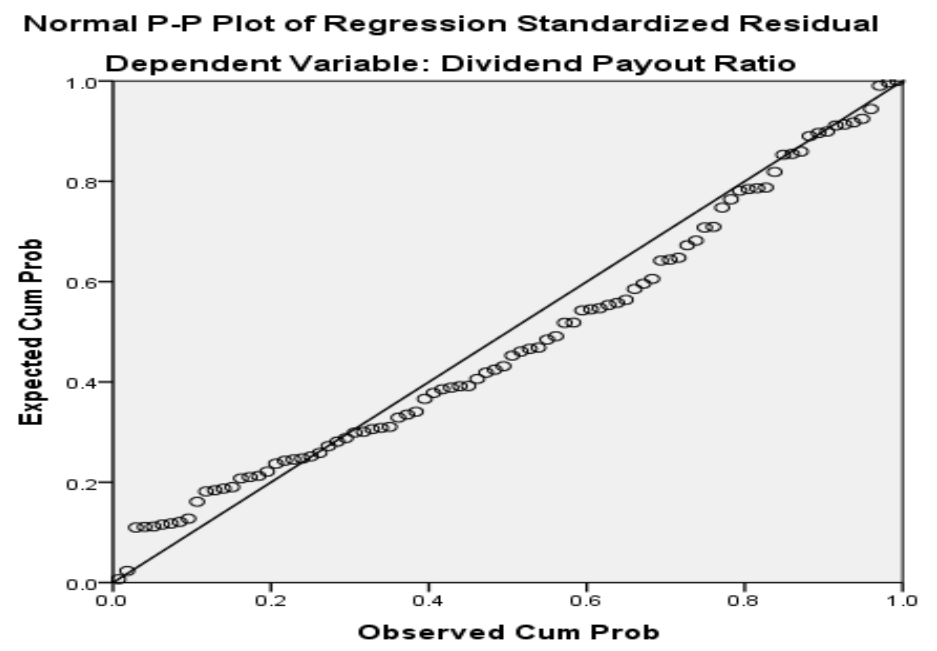

\section{Gambar 1. Hasil Uji Normalitas menggunakan Grafik Normal Probability Plot}

Sumber: Data sekunder diolah, 2019.

Variabel DER (X2) memiliki nilai mean sebesar 0,751308 (dengan standar deviasi 0,6331673); dimana nilai minimum sebesar 0,0709 terletak pada PT. Industri Jamu dan Farmasi Sido Muncul Tbk. di tahun 2014, sementara nilai maksimum sebesar 3,0286 terletak pada PT. Multi Bintang Indonesia Tbk. di tahun 2014.

Variabel Cash Ratio (X3) memiliki nilai mean sebesar 1,129332 (dengan standar deviasi 1,2810598); dimana nilai minimum sebesar 0,0048 terletak pada PT. HM. Sampoerna Tbk. di tahun 2014, sementara nilai maksimum sebesar 6,0516 terletak pada PT. Delta Djakarta Tbk. di tahun 2017.

Variabel DPR (Y) mempunyai nilai mean sebesar 0,534803 (dengan standar deviasi 0,3172716); dimana nilai minimum sebesar 0,0837 terletak pada PT. Nippon Indosari Corpindo Tbk. di tahun 2014, sementara nilai maksimum sebesar 1,5400 terletak pada PT. Merck Tbk. di tahun 2015.

\section{Hasil Uji Asumsi Klasik \\ Hasil Uji Normalitas}

Uji normalitas ini dianalisis menggunakan dua cara, yaitu analisis grafik dan uji statistik. Untuk cara pertama, uji normalitas mempergunakan grafik Normal Probability
Plot. Berdasarkan Gambar 1 terlihat bahwa titik-titik pola data sudah menyebar di seputar garis normal, serta penyebarannya telah mengikuti garis diagonal. Dengan demikian, secara grafik, diperoleh data dari model analisis penelitian ini diidentifikasi telah terdistribusi normal.

Untuk cara kedua, uji normalitas menggunakan pendekatan Kolmogorov-Smirnov. Berdasarkan Tabel 3 diperoleh nilai Asymp. Sig (2-tailed) sebesar 0,449 adalah lebih besar dari $0,05(\alpha)$. Dengan demikian, cara kedua juga memperkuat bahwa data model penelitian ini dinyatakan telah terdistribusi normal.

\section{Hasil Uji Multikolinearitas}

Berdasarkan Tabel 4 diperoleh bahwa hasil uji multikolinearitas menunjukkan ROE $(\mathrm{X} 1, T=0,540 ; V I F=1,850)$, DER $(\mathrm{X} 2, T=$ 0,413; VIF = 2,419), dan Cash Ratio (X3, $T=$ 0,700; $V I F=1,429)$ memiliki nilai Tolerance (T) lebih besar dari 0,10 serta nilai VIF lebih kecil dari 10. Dengan demikian, dinyatakan bahwa tidak terjadi gejala multikolinearitas dalam model analisis penelitian ini.

\section{Hasil Uji Autokorelasi}

Berdasarkan Tabel 5 diperoleh nilai Durbin-Watson (DW) sebesar 1,986. Dikait- 
kan dengan jumlah sampel sebanyak 90 observasi dan dengan tiga variabel independen, maka didapati nilai batas bawah $(d l)$ sebesar 1,5889 serta nilai batas atas $(d u)$ sebesar 1,7264. Hasil analisis uji autokorelasi karenanya menemukan bahwa nilai DW terletak di antara kedua nilai batas tersebut. Dengan demikian dapat dinyatakan bahwa tidak ada masalah autokorelasi positif dan negatif di dalam model penelitian ini.

\section{Hasil Uji Heteroskedastisitas}

Terdapat dua cara untuk menguji kemungkinan terjadinya heteroskedastisitas di dalam model regresi, yaitu dengan melakukan analisis grafik Scatterplot serta analisis statistik menggunakan uji Park (Ghozali, 2016; Sanusi, 2014).

Tabel 3. Hasil Uji Normalitas

One-Sample Kolmogorov-Smirnov Test

\begin{tabular}{|c|c|c|}
\hline \multicolumn{3}{|c|}{ Unstandardized Residual } \\
\hline $\mathrm{N}$ & & 90 \\
\hline & Mean & 0E-7 \\
\hline \multirow[t]{2}{*}{ Normal Parameters ${ }^{\mathrm{a}, \mathrm{b}}$} & Std. Deviation & .23674281 \\
\hline & Absolute & .091 \\
\hline \multirow[t]{2}{*}{ Most Extreme Differences } & Positive & .091 \\
\hline & Negative & -.084 \\
\hline Kolmogorov-Smirnov Z & & .861 \\
\hline Asymp. Sig. (2-tailed) & & .449 \\
\hline
\end{tabular}

a. Test distribution is Normal.

b. Calculated from data.

Sumber: Data sekunder diolah, 2019.

Tabel 4. Hasil Uji Multikolinearitas

\section{Coefficients $^{\mathrm{a}}$}

\begin{tabular}{|c|c|c|c|c|c|c|c|c|}
\hline \multirow[t]{2}{*}{ Mode } & & \multicolumn{2}{|c|}{$\begin{array}{c}\text { Unstandardized } \\
\text { Coefficients }\end{array}$} & \multirow{2}{*}{$\begin{array}{c}\begin{array}{c}\text { Standardized } \\
\text { Coefficients }\end{array} \\
\text { Beta }\end{array}$} & \multirow[t]{2}{*}{$\mathrm{t}$} & \multirow[t]{2}{*}{ Sig. } & \multicolumn{2}{|c|}{ Collinearity Statistics } \\
\hline & & B & $\begin{array}{l}\text { Std. } \\
\text { Error }\end{array}$ & & & & Tolerance & VIF \\
\hline \multirow{4}{*}{1} & (Constant) & .426 & .061 & & 7.032 & .000 & & \\
\hline & $\mathrm{X} 1$ & .659 & . 087 & .832 & 7.600 & .000 & .540 & 1.850 \\
\hline & $\mathrm{X} 2$ & -.164 & .063 & -.328 & -2.621 & .010 & .413 & 2.419 \\
\hline & $\mathrm{X} 3$ & .023 & .024 & .094 & .978 & .331 & .700 & 1.429 \\
\hline
\end{tabular}

a. Dependent Variable: Y.

Sumber: Data sekunder diolah, 2019. 
Tabel 5. Hasil Uji Autokorelasi dan Analisis Koefisien Determinasi

\begin{tabular}{lrrrrr}
\multicolumn{5}{c}{ Model Summary $^{\mathbf{b}}$} \\
\hline Model & $\mathrm{R}$ & R Square & Adjusted R Square & $\begin{array}{c}\text { Std. Error of the } \\
\text { Estimate }\end{array}$ & Durbin-Watson \\
\hline 1 & $.666^{\mathrm{a}}$ & .443 & .424 & .2408366 & 1.986 \\
\hline
\end{tabular}

a. Predictors: (Constant), X3, X1, X2,

b. Dependent Variable: Y

Sumber: Data sekunder diolah, 2019.

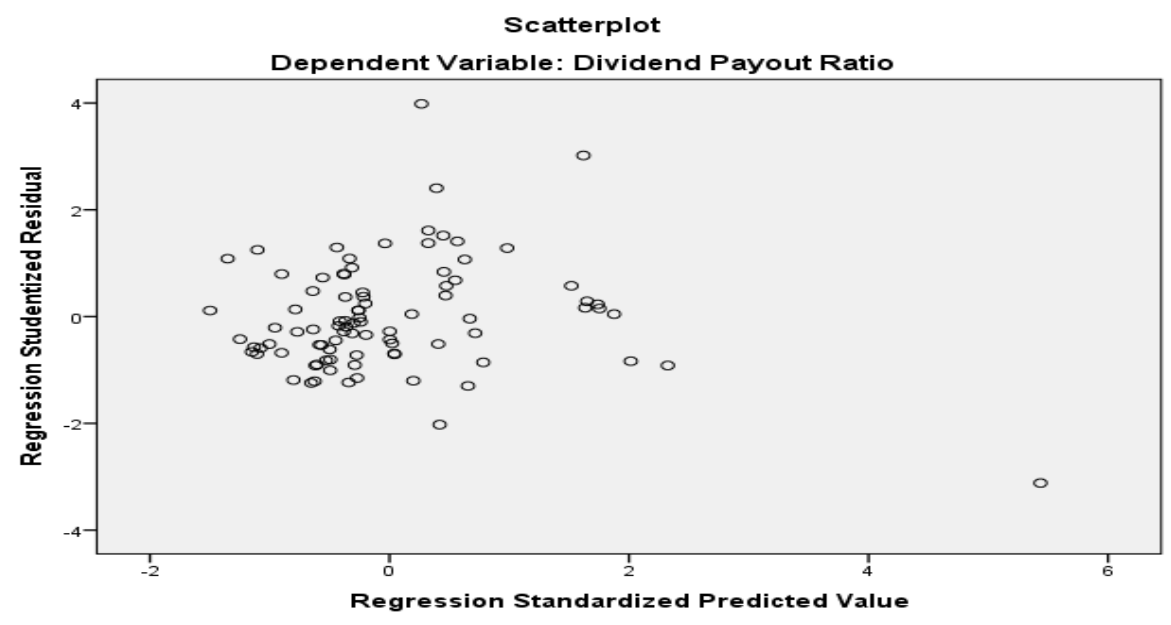

\section{Gambar 2. Grafik Scatterplot}

Sumber: Data sekunder diolah, 2019.

\section{Tabel 6. Hasil Uji Heteroskedastisitas}

\section{Coefficients $^{\mathrm{a}}$}

\begin{tabular}{|c|c|c|c|c|c|c|}
\hline \multirow[t]{2}{*}{ Model } & & \multicolumn{2}{|c|}{$\begin{array}{l}\text { Unstandardized } \\
\text { Coefficients }\end{array}$} & \multirow{2}{*}{$\begin{array}{c}\text { Standardized } \\
\text { Coefficients } \\
\text { Beta }\end{array}$} & \multirow[t]{2}{*}{$\mathrm{t}$} & \multirow[t]{2}{*}{ Sig. } \\
\hline & & B & Std. Error & & & \\
\hline \multirow{4}{*}{1} & (Constant) & -3.903 & .512 & & -7.629 & .000 \\
\hline & $\mathrm{X} 1$ & .867 & .732 & .171 & 1.183 & .240 \\
\hline & $\mathrm{X} 2$ & -.719 & .529 & -.225 & -1.359 & .178 \\
\hline & $\mathrm{X} 3$ & -.067 & .201 & -.042 & -.333 & .740 \\
\hline
\end{tabular}

a. Dependent Variable: Y

Sumber: Data sekunder diolah, 2019.

\section{Hasil Analisis Regresi Berganda}

Bagian ini menguraikan hasil analisis atas model regresi berganda yang dipergunakan dalam penelitian ini. Tabel 7 merangkum hasil analisis, dan diperoleh persamaan:

$$
\mathrm{Y}=0,426+0,659 \mathrm{X} 1-0,164 \mathrm{X} 2+0,023 \mathrm{X} 3
$$

Penjabaran dari model persamaan itu adalah sebagai berikut. Nilai koefisien regresi untuk variabel X1 sebesar 0,659 menunjuk- kan bahwa ROE memiliki pengaruh dengan arah yang positif atau searah terhadap DPR; yang berarti bila nilai ROE mengalami kenaikan maka DPR juga akan mengalami kenaikan nilai, atau sebaliknya bila nilai ROE mengalami penurunan maka DPR juga akan mengalami penurunan nilai, ceteris paribus.

Nilai koefisien regresi dari variabel X2 sebesar -0,164 menunjukkan bahwa DER juga 
memiliki pengaruh dengan arah yang negatif atau berlawanan terhadap DPR; yang berarti bila nilai DER mengalami kenaikan maka DPR akan mengalami penurunan nilai, atau sebaliknya apabila nilai DER mengalami penurunan maka DPR akan mengalami kenaikan nilai, ceteris paribus.

Nilai koefisien regresi untuk variabel X3 sebesar 0,023 menunjukkan bahwa Cash Ratio juga mempunyai pengaruh dengan arah yang positif terhadap DPR; yang berarti bila nilai Cash Ratio mengalami kenaikan maka DPR akan mengalami kenaikan nilai, atau sebaliknya bila nilai Cash Ratio mengalami penurunan maka DPR juga akan mengalami penurunan nilai, ceteris paribus.

Dengan demikian, bisa dinyatakan bahwa terdapat dua variabel independen yang dimasukkan dalam model analisis penelitian ini terbukti memiliki pengaruh bersifat positif atau searah terhadap DPR, yaitu ROE dan Cash Ratio. Sementara itu, variabel independen lainnya dalam model analisis penelitian ini, yaitu DER, terbukti mengalami pengaruh yang bersifat negatif ataupun berlawanan terhadap DPR.

\section{Hasil Analisis Koefisien Determinasi}

Bagian ini menguraikan hasil analisis koefisien determinasi atas model analisis yang dipergunakan dalam penelitian ini.
Berdasarkan Tabel 5 diperoleh nilai koefisien determinasi mempergunakan angka Adjusted $R^{2}$ adalah sebesar 0,424. Hasil ini berarti bahwa ROE, DER dan Cash Ratio sebagai variabel independen mampu berkontribusi ataupun menjelaskan variasi yang terjadi pada DPR sebesar $42,4 \%$. Sementara itu, sisa nilai sebesar 57,6 menyatakan bahwa variasi dari DPR juga dipengaruhi variabelvariabel lain yang tidak dicakup dalam model penelitian ini.

\section{Hasil Uji Hipotesis Penelitian Hasil Uji Parsial}

Pada bagian ini diuraikan hasil uji hubungan parsial antara variabel independen dengan variabel dependen di dalam model analisis yang digunakan dalam penelitian ini.

Tabel 7, selain menyatakan tentang hasil analisis regresi linier berganda, juga menunjukkan hasil uji parsial atas tiap-tiap variabel independen atas variabel dependen. Hasil pertama bahwa untuk variabel X1 diperoleh $t$-hitung sebesar 7,600 dengan nilai Sig. $t$ sebesar 0,000. Dikarenakan nilai Sig. $t$ lebih kecil dari 0,05 $(\alpha)$, maka dinyatakan bahwa ROE terbukti mempunyai pengaruh parsial bersifat signifikan terhadap DPR. Dengan demikian, hipotesis pertama (H1) dari penelitian ini dapat dterima atau dibuktikan.

Tabel 7. Hasil Analisis Regresi Linier Berganda dan Uji Parsial Coefficients $^{\text {a }}$

\begin{tabular}{|c|c|c|c|c|c|c|}
\hline \multirow[t]{2}{*}{ Model } & & \multicolumn{2}{|c|}{$\begin{array}{l}\text { Unstandardized } \\
\text { Coefficients }\end{array}$} & \multirow{2}{*}{$\begin{array}{c}\text { Standardized } \\
\text { Coefficients } \\
\text { Beta }\end{array}$} & \multirow[t]{2}{*}{$\mathrm{t}$} & \multirow[t]{2}{*}{ Sig. } \\
\hline & & B & Std. Error & & & \\
\hline \multirow{4}{*}{1} & (Constant) & .426 & .061 & & 7.032 & .000 \\
\hline & $\mathrm{X} 1$ & .659 & .087 & .832 & 7.600 & .000 \\
\hline & $\mathrm{X} 2$ & -.164 & .063 & -.328 & -2.621 & .010 \\
\hline & $\mathrm{X} 3$ & .023 & .024 & .094 & .978 & .331 \\
\hline
\end{tabular}

a. Dependent Variable: Y

Sumber: Data sekunder diolah, 2019. 
Tabel 8. Hasil Uji Simultan

\begin{tabular}{rlrrrrr}
\multicolumn{8}{c}{ ANOVA $^{\text {a }}$} \\
\hline Model & & Sum of Squares & Df & Mean Square & F & \multicolumn{1}{c}{ Sig. } \\
\hline \multirow{2}{*}{1} & Regression & 3.971 & 3 & 1.324 & 22.819 & $.000^{\text {b }}$ \\
& Residual & 4.988 & 86 & .058 & & \\
& Total & 8.959 & 89 & & & \\
\hline
\end{tabular}

a. Dependent Variable: Y

b. Predictors: (Constant), X3, X1, X2

Sumber: Data sekunder diolah, 2019.

Hasil kedua berdasarkan Tabel 7 yaitu untuk variabel X2 teridentifikasi $t$-hitung sebesar -2,621 dengan nilai Sig. $t$ sebesar 0,010. Karena nilai Sig. $t$ lebih kecil dari 0,05 $(\alpha)$, maka dinyatakan bahwa DER terbukti memiliki pengaruh parsial yang bersifat signifikan pada DPR. Dengan demikian, hipotesis kedua $(\mathrm{H} 2)$ dari penelitian ini dapat dterima.

Hasil ketiga berdasarkan Tabel 7 adalah untuk variabel X3 diidentifikasi $t$-hitung sebesar 0,978 dengan nilai Sig. $t$ sebesar 0,331. Karena nilai Sig. $t$ diperoleh lebih besar dari 0,05 $(\alpha)$, sehingga dinyatakan bahwa Cash Ratio terbukti memiliki pengaruh parsial yang tidak signifikan atas DPR. Dengan demikian, hipotesis ketiga (H3) dari penelitian ini tidak dapat dterima.

\section{Pembahasan}

\section{Pengaruh ROE terhadap DPR}

Hasil penelitian ini memberikan bukti bahwa Return on Equity (ROE) berpengaruh secara positif dan signifikan pada Dividend Payout Ratio (DPR) pada perusahaan gopublik sektor barang konsumsi tahun 20142018. Hasil ini berarti tingkat profitabilitas perusahaan sektor barang konsumsi secara langsung berdampak pada peningkatan nilai dividen yang dibagikan oleh perusahaan. Kebijakan ini timbul karena pihak manajemen meramalkan adanya peluang penghasilan yang bagus di masa mendatang, sehingga cenderung memberikan sinyal positif bahwa perusahaan berencana membagikan dividen dalam nilai yang lebih besar pada pemegang saham serta menciptakan persepsi positif dalam benak investor.

Hasil penelitian ini memperluas hasil penelitian terdahulu, diantaranya Sarmento \& Dana (2016) dan Junaidi et al. (2014) yang juga menyatakan bahwa ROE berpengaruh atas DPR. Namun demikian, hasil penelitian ini berbeda dengan temuan Lioew et al. (2014) yang menyatakan bahwa ROE tidak berpengaruh terhadap DPR. Karenanya dinilai masih diperlukan penelitian-penelitian berikut nya dengan topik serupa untuk memberi konklusi atas gap hasil ini pada sektor perusahaan yang berbeda.

\section{Pengaruh DER terhadap DPR}

Hasil penelitian ini menemukan bukti bahwa Debt to Equity Ratio (DER) berpengaruh secara negatif dan bersifat signifikan terhadap Dividend Payout Ratio (DPR) pada perusahaan go-publik sektor barang konsumsi tahun 2014-2018. Ini berarti tingkat DER dari perusahaan sektor barang konsumsi secara nyata memberi dampak kepada penurunan nilai dividen yang dibagikan oleh perusahaan. Dikarenakan tingginya porsi hutang yang digunakan untuk struktur modal, sehingga semakin tinggi pula jumlah beban kewajiban yang harus dibayarkan perusahaan. Kondisi ini selanjutnya berdampak pada menurunnya nilai dividen yang dibagikan kepada para pemegang saham. 
Hasil penelitian ini sejalan dengan hasilhasil penelitian terdahulu, diantaranya milik Atmoko et al. (2017) yang mengidentifikasi bahwa DER berpengaruh atas DPR. Akan tetapi, hasil penelitian ini berbeda dengan milik Hanif \& Bustamam (2017) dan Kautsar (2012) yang berargumen bahwa DER tidak berpengaruh pada DPR. Lebih jauh, hasil penelitian ini mendukung pemikiran Junaidi et al. (2014) bahwa semakin besar nilai DER mencerminkan adanya risiko perusahaan yang relatif tinggi. Hal ini menunjukkan bahwa perusahaan itu masih membutuhkan modal pinjaman untuk membiayai operasional perusahaan. Jika perusahaan masih membutuhkan modal pinjaman, dapat dipastikan keuntungan yang dihasilkan perusahaan akan difokuskan untuk mengembalikan pokok pinjaman plus bunga pinjamannya. Sebagai konsekuensi, para investor cenderung bersikap menghindari saham-saham yang ditengarai memiliki nilai DER tinggi.

\section{Pengaruh Cash Ratio terhadap DPR}

Hasil penelitian ini memperoleh bukti bahwa Cash Ratio memiliki pengaruh namun tidak signifikan kepada Dividend Payout Ratio (DPR) pada perusahaan go-publik sektor barang konsumsi tahun 2014-2018. Hal ini dinilai karena pihak manajemen dari perusahaan tidak mempertimbangkan posisi cash ratio sebagai variabel penting dalam menentukan DPR. Dengan kata lain, besar kecilnya kas yang tersedia tidak akan berpengaruh pada nilai pembayaran dividen, karena perusahaan telah mempertimbangkan hal-hal lain dalam proses pembayaran seperti pinjaman hutang. Kondisi ini memberikan persepsi positif bagi para investor sehingga mereka tetap yakin bahwa perusahaan akan memberikan penghasilan yang lebih baik di masa akan datang.

Hasil penelitian ini sejalan dengan sejumlah hasil penelitian terdahulu, seperti milik Farida \& Sunandar (2015) serta Ambarwati (2017) yang menemukan bahwa Cash Ratio tidak berpengaruh pada DPR. Akan tetapi, hasil penelitian ini berbeda dengan temuan Janifairus et al. (2013) yang menemukan bahwa Cash Ratio berpengaruh atas DPR.

Lebih jauh, hasil penelitian ini tidak sejalan dengan argumen Winarko (2017) yang menyebutkan bahwa Cash Ratio sebagai salah satu rasio likuiditas perusahaan menjadi faktor penting yang seharusnya diperhitungkan sebelum menetapkan suatu keputusan menetapkan besaran nilai dividen yang akan dibagikan pada pihak pemegang saham. Berbeda dengan pemikiran Winarko (2017), hasil penelitian ini menyatakan Cash Ratio belum menjadi pertimbangan utama karena dianggap mempengaruhi pembayaran dividen, serta diargumentasikan belum bisa dijadikan alat yang bisa digunakan untuk mengukur besaran uang kas yang tersedia untuk membayar hutang.

\section{SIMPULAN}

Berdasarkan hasil-hasil penelitian yang telah dikemukakan, bisa disimpulkan bahwa secara parsial, Return on Equity (ROE) memiliki pengaruh secara positif dan signifikan terhadap Dividend Payout Ratio (DPR); Debt to Equity Ratio (DER) memiliki pengaruh secara negatif dan signifikan pada DPR; serta, Cash Ratio mempunyai pengaruh yang tidak signifikan pada DPR. Secara simultan, ROE, DER dan Cash Ratio mempunyai pengaruh signifikan pada DPR.

Hasil penelitian ini diharapkan bermanfaat sebagai bahan pertimbangan bagi penentuan upaya-upaya untuk menjaga ataaupun meningkatkan kinerja perusahaan berhubungan dengan manajemen ROE, DER dan Cash Ratio, sehingga dapat menghasilkan kebijakan DPR yang mampu memberikan mensejahterakan bagi pemegang saham. 
Temuan penelitian ini juga diharapkan dapat menambah wawasan referensi bagi para peneliti berikutnya, khususnya berkenaan dengan topik hubungan antara ROE, DER dan Cash Ratio dengan DPR.

Bagaimanapun, peneliti menyadari masih adanya beberapa kelemahan di dalam penelitian ini yang diharapkan bisa diatasi oleh para peneliti berikutnya. Kelemahan pertama adalah bahwa perusahaan yang menjadi sampel penelitian hanya terbatas pada perusahaan sektor barang konsumsi, sehingga hasil dari penelitian ini dipandang tidak dapat digeneralisasikan untuk semua perusahaan yang go-publik dalam Bursa Efek Indonesia. Kelemahan kedua adalah hasil analisis determinasi menemukan bahwa masih terdapat variabel-variabel lainnya selain ROE, DER dan Cash Ratio yang dinilai bisa mempengaruhi DPR namun tidak dicakup dalam model penelitian ini. Para peneliti berikutnya direkomendasikan untuk melibatkan lebih banyak variabel dalam model penelitian mereka, sehingga temuan-temuan yang diperoleh dapat memperkaya dan memperdalam wawasan ilmu pengetahuan mengenai faktor-faktor yang diduga mempengaruhi variasi DPR.

\section{REFERENSI}

Ambarwati, D. 2017. Analisis Pengaruh DER, ROA dan CR terhadap Dividend Payout Ratio pada Perusahaan Pertambangan yang Terdaftar dalam Bursa Efek Indonesia (BEI) Tahun 2011-2015. Jurnal Penelitian dan Kajian Ilmiah. 15(3), Juli.

Atmoko, Y., Defung, F. \& Tricahyadinata, I. 2017. Pengaruh Return on Assets, Debt to Equity Ratio, dan Firm Size terhadap Dividend Payout Ratio. KINERJA. 14(2): 103-109.

Darmadji, T. \& Fakhruddin, H.M. 2012. Pasar Modal di Indonesia. Edisi 3. Jakarta: PT. Salemba Empat.
Fahmi, I. 2016. Pengantar Manajemen Keuangan. Bandung: Alfabeta.

Farida, I. \& Sunandar, S. 2015. Pengaruh Cash Ratio, Growth, Debt to Equity Ratio dan Kepemilikan Publik terhadap Dividend Payout Ratio pada Perusahaan yang Terdaftar di Bursa Efek Indonesia. Jurnal Fokus Bisnis, 14(2): 25-43.

Ghozali, I. 2016. Aplikasi Analisis Multivariate dengan Program SPSS 23. Semarang: Badan Penerbit Universitas Diponegoro.

Hanif, M. \& Bustamam, B. 2017. Pengaruh Debt to Equity Ratio, Return on Asset, Firm Size, dan Earning per Share terhadap Dividend Payout Ratio (Studi pada Perusahaan Manufaktur yang Terdaftar di Bursa Efek Indonesia Tahun 2011-2015). Jurnal Ilmiah Mahasiswa Ekonomi Akuntansi (JIMEKA). 2(1): 73-81.

Hery. 2016. Analisis Laporan Keuangan. Jakarta: PT. Grasindo.

Janifairus, J.B., Hidayat, R. dan Husaini, A. 2013. Pengaruh Return on Asset, Debt to Equity Ratio, Assets Growth, dan Cash Ratio terhadap Dividend Payout Ratio (Studi pada Perusahaan Manufaktur Barang Konsumsi yang Listing di Bursa Efek Indonesia Periode 2008-2010). Jurnal Administrasi Bisnis (JAB). 1(1): 161-169.

Junaidi, Nasir, A. dan Wiguna, M. 2014. Pengaruh Return on Equity (ROE), Cash Ratio (CR), Debt to Equity Ratio (DER) dan Earning per Share (EPS) terhadap Dividen Payout Ratio pada Perusahaan Jakarta Islamic Index yang Listing di BEI Periode 2008-2012. JOM FEKON. 1(2): 1-12.

Kasmir. 2012. Analisis Laporan Keuangan. Cetakan Kelima. Jakarta: PT. Raja Grafindo Persada.

Kautsar, A. 2012. Pengaruh Return on Equity (ROE), Debt to Equity Ratio (DER), Investment Opportunity Set (IOS), dan Inflasi terhadap Dividend Payout Ratio (DPR) (Studi: Pada Perusahaan Property and Real Estate yang Listed di 
BEI Tahun 2006-2009). BISMA Jurnal Bisnis dan Manajemen. 4(2): 154-166.

Lioew, A.M., Murni, S. dan Mandagie, Y. 2014. ROA, ROE, NPM Pengaruhnya terhadap Dividen Payout Ratio pada Perusahaan Perbankan dan Financial Institusi yang Terdaftar di BEI Periode 2010-2012. Jurnal EMBA. 2(2): 14061416.

Purnomo, A.D. dan Widianti, R. 2017. Pengaruh Debt to Equity Ratio (DER) dan Current Ratio (CR) terhadap Dividend Payout Ratio (DPR) pada Perusahaan Aneka Industri yang Terdaftar di BEI. The Asia Pacific Journal of Management. 4(3): 109116.

Sanusi, A. 2014. Metodologi Penelitian Bisnis. Cetakan Keempat. Jakarta: Salemba Empat.
Sarmento, J.D.C. dan Dana, M. 2016. Pengaruh Return on Equity, Current Ratio, dan Earning per Share terhadap Kebijakan Dividen pada Perusahaan Keuangan. E-Jurnal Manajemen Unud. 5(7): $4224-4252$.

Sudana, I.M. 2015. Manajemen Keuangan Perusahaan. Jakarta: Erlangga.

Van Horne, J. \& Wachowicz, J. 2012. Prinsip-Prinsip Manajemen Keuangan. Edisi 13 Jilid 1. Jakarta: PT. Salemba Empat.

Winarko, S.P. 2017. Pengaruh Cash Ratio, Debt to Equity Ratio, Return on Assets, dan Tax Rate terhadap Dividend Payout Ratio pada Perusahaan Manufaktur yang Terdaftar di Bursa Efek Indonesia. Jurnal Akuntansi \& Ekonomi FE. UN PGRI Kediri. 2(1): Maret. 